\title{
Efficient mischarging of a viral tRNA-like structure and aminoacylation of a minihelix containing a pseudoknot: histidinylation of turnip yellow mosaic virus RNA
}

\author{
Joëlle Rudinger, Catherine Florentz, Theo Dreher ${ }^{1}$ and Richard Giegé ${ }^{*}$ \\ UPR Structure des Macromolécules Biologiques et Mécanismes de Reconnaissance, Institut de \\ Biologie Moléculaire et Cellulaire du CNRS, 15, rue René Descartes, F-67084 Strasbourg Cedex, \\ France and ${ }^{1}$ Department of Agricultural Chemistry, Oregon State University, Corvallis, \\ OR 97331-6502, USA
}

Received February 14, 1992; Revised and Accepted March 26, 1992

\begin{abstract}
Mischarging of the valine specific tRNA-like structure of tumip yellow mosalc virus (TYMV) RNA has been tested in the presence of purtfied arginyl-, aspartyl-, histidinyl-, and phenylalanyl-tRNA synthetases from bakers' yeast. Important mischarging of a 264 nucleotide-long transcript was found with histidinyltRNA synthetase which can acylate this fragment up to a level of 25\% with a loss of specificity (expressed as $V_{\max }\left(K_{m}\right.$ ratios) of only 100 fold as compared to a yeast tRNA ${ }^{\text {the }}$ transcript. Experiments on transcripts of various lengths indicate that the minimal valylatable fragment $(n=88)$ is the most efficient substrate for histidiny-tRNA synthetase, with kinetic characteristics similar to those found for the control tRNA His transcript. Mutations in the anticodon or adjacent to the $3^{\prime}$ CCA that severely affect the valylation capacity of the 264 nucleotlde long TYMV fragment are without negative effect on its mischarging, and for some cases even improve its efficiency. A short fragment $(n=42)$ of the viral RNA containing the pseudoknot and corresponding to the amino acid accepting branch of the molecule is an efficient histidine acceptor.
\end{abstract}

\section{INTRODUCTION}

The genomic RNAs of a number of positive strand RNA plant viruses possess at their $3^{\prime}$ ends a tRNA-like structure that is able to interact with various tRNA specific proteins, including aminoacyl-tRNA synthetases, (ATP, CTP):tRNA nucleotidyl transferase, elongation factors and RNAse $P$ (reviewed in 1). The most characteristic feature of these molecules is their ability to be efficiently aminoacylated in vitro (e.g. $2-5$ ) and indeed aminoacylation also occurs in vivo (6-8), in competition with the charging of cellular tRNAs. The role of aminoacylation in the viral life cycle remains unknown. Based on work with brome mosaic virus (BMV) showing that the tRNA-like structure is involved both in tRNA mimicry and in genome replication $(9-12)$, hypotheses have favoured a role for aminoacylation in RNA replication (13). A role in the coordination of genome expression and replication is also possible (14). There is no evidence that aminoacylated tRNA-like structures are able to interact with ribosomes to, for instance, modify protein synthesis profiles during viral infection (15), an idea supported by recent studies on BMV RNA (16). Further, it is uncertain at present whether aminoacylation is an essential function for all the aminoacylatable viral RNAs. Aminoacylation in vitro and virus replication in vivo are highly correlated for turnip yellow mosaic virus (TYMV) RNA (17), but apparently not for BMV RNA (12, 18). The fact that the viral tRNA-like structures are substrates for (ATP, CTP):tRNA nucleotidyl transferase suggests a role for these structures as telomeres $(19,20)$, a property that has been demonstrated in the case of BMV (21).

Only a limited number of aminoacyl-tRNA synthetases have been found to acylate plant viral RNAs, which have been considered to be specific substrates for the relevant aminoacyltRNA synthetases : tymoviral RNA for valyl-tRNA synthetase (ValRS), bromo-, cucumo- and hordeiviral RNA for tyrosyltRNA synthetase (TyrRS), and tobamoviral RNA (with one exception) for histidinyl-tRNA synthetase (HisRS) (1). Recognition by a limited set of aminoacyl-tRNA synthetases could be due to peculiar structural features of those synthetases that are able to accommodate the non-canonical viral tRNAs. In this paper we investigate further whether viral RNAs can be significantly charged by aminoacyl-tRNA synthetases other than their 'cognate' enzymes listed above, including synthetases not currently known to charge viral RNAs. This possibility is suggested by the fact that certain canonical tRNAs, in particular valine-specific tRNAs, are well known to be mischarged by different aminoacyl-tRNA synthetases (e.g. 22-25). Mischarging of viral RNAs might also be expected due to the lack of modified

* To whom correspondence should be addressed 
bases, whose absence in tRNA transcripts causes a structural relaxation (26), that results in relaxed specificity : e.g. unmodified yeast tRNA ${ }^{\mathrm{Asp}}$ transcripts have enhanced mischarging by ArgRS (27). As our model molecule for these studies we have chosen the valylatable TYMV RNA, whose tRNA-like structure most closely resembles canonical tRNAs (Fig. 1A), and which might therefore be most readily recognized by other synthetases. The selection of TYMV RNA was further supported by the observation of Van Belkum et al. showing that a crude Escherichia coli synthetase preparation could incorporate radioactive amino acids other than valine in RNA extracted from TYMV virions (28). However, the possibility that contaminating tRNA was present was not excluded in this work.

In the present studies, we have tested the charging of various TYMV RNA 3' end fragments prepared by in vitro transcription using four highly enriched yeast aminoacyl-tRNA synthetases, and have found significant aminoacylation by HisRS. Kinetic data characterizing this novel mischarging reaction of TYMV RNA will be presented and virological implications as well as the perspectives for the $t R N A /$ synthetase recognition problem will be discussed.

\section{MATERIALS AND METHODS}

\section{Materials}

Yeast ValRS, AspRS and ArgRS were purified to homogeneity according to established procedures (29-31). Yeast HisRS was an enzyme preparation enriched by chromatographies on DEAEcellulose, hydroxyapatite and phosphocellulose (32). Pure yeast PheRS was a gift from M. Baltzinger (IBMC, Strasbourg). Yeast tRNA $^{\mathrm{Val}}$ was purified according to an established procedure (29). T7 RNA polymerase was prepared according to (33).

$\mathrm{L}-\left[{ }^{3} \mathrm{H}\right]$ valine $(25 \mathrm{Ci} / \mathrm{mmol}), \mathrm{L}-\left[{ }^{3} \mathrm{H}\right]$ phenylalanine $(30$ $\mathrm{Ci} / \mathrm{mmol}), \mathrm{L}-\left[{ }^{3} \mathrm{H}\right]$ aspartic acid $(20 \mathrm{Ci} / \mathrm{mmol}), \mathrm{L}-\left[{ }^{14} \mathrm{C}\right]$ arginine (58 Ci/mmol), and $\mathrm{L}-\left[{ }^{14} \mathrm{C}\right]$ histidine $(300 \mathrm{mCi} / \mathrm{mmol})$ were from Amersham France (Les Ulis). Restriction enzymes BstN1 and EcoT22I were purchased from New England Biolabs (Beverly, MA, USA) and United States Biochemical Corporation (Cleveland, OH, USA), and RNAsin from Promega (Madison, WI, USA).

\section{Cloning of synthetic genes containing the TYMV tRNA-like structure}

cDNAs corresponding to different lengths of the TYMV RNA $3^{\prime}$ end were cloned next to the T7 RNA polymerase promoter into plasmid pIBI76 as described by (11). These clones containing cDNA of 258, 109, and 82 nucleotides from the viral sequence and an additional GGGAGA hexanucleotide sequence at their 5 '-end, were named pTYSma, pTYDde and pTYAlu, respectively. They contain a BstN1 restriction site at the precise end of the sequence encoding the tRNA-like sequence. Mutations have been introduced into clone pTYSma, giving rise to transcripts differing from the wild-type sequence in the middle position of the CAC anticodon (pTYSma-G56, pTYSma-U56) or adjacent to the $3^{\prime}$ CCA terminus (pTYSma-C4 and pTYSmaG4). Clone pTYAA consisting of the amino acid accepting arm $(n=42)$ of the TYMV tRNA-like structure adjacent to the T7 RNA polymerase promoter was created by oligonucleotidedirected mutagenesis of pTYAlu. Site directed mutagenesis has been performed as described in (34).

\section{Cloning of synthetic yeast tRNA ${ }^{\text {His }}$ gene}

Ten oligonucleotides corresponding to the consensus sequence of the T7 RNA polymerase promoter and to the sequence of yeast $\mathrm{tRNA}^{\text {His }}$ were ligated and inserted into a derivative of pUC18 linearised with BamHI and HindIII as described for yeast tRNA $^{\text {Asp }}$ synthetic gene (26). This plasmid contains also the origin of replication of phage $\mathrm{Fl}$ and an ampicilline resistance gene. An EcoT22I restriction site was introduced at the end of the tRNA sequence. This allows, after linearisation of the plasmid and transcription, for the production of transcripts ending with a 3' CCA sequence. BstN1, the restriction enzyme generally used for linearisation of DNA encoding tRNA sequences, could not be used here since there is an internal BstN1 site in the tRNA sequence.

\section{In vitro transcription}

Since the efficiency of in vitro transcription by T7 RNA polymerase is extremely sensitive to the sequence downstream the promoter, experimental conditions have been worked out for the three types of molecules studied. Plamsids encoding the TYMV sequences (except pTYAA) were linearized with BstN1 and transcribed as described in (34) except that the temperature was $30^{\circ} \mathrm{C}$. pTYAA, encoding the 42 nucleotide long acceptor arm was transcribed under the following conditions: BstN1-linearised plasmid $(15 \mu \mathrm{g})$ was incubated 4 hours at $37^{\circ} \mathrm{C}$ in $40 \mathrm{mM}$ Tris- $\mathrm{HCl} \mathrm{pH} 8.1$ (at $37^{\circ} \mathrm{C}$ ), $20 \mathrm{mM} \mathrm{MgCl}_{2}, 1 \mathrm{mM}$ spermidine, $10 \mathrm{mM}$ dithioerythritol, $0.01 \%$ Triton X 100, $4 \mathrm{mM}$ of each nucleoside triphosphate, $120 \mathrm{U}$ RNAsin and $150 \mathrm{U}$ of T7 RNA polymerase in $150 \mu \mathrm{l}$. After phenol extraction and ethanol precipitation, the tRNA-like transcripts were purified by HPLC on a TSK 400 column (Biorad, Paris, France) in $0.2 \mathrm{M}$ sodium acetate $\mathrm{pH} 6.5,1 \%$ methanol. Fractions containing fulllength transcripts were ethanol precipitated. Since T7 RNA polymerase adds generally one or two additional nucleotides to the $3^{\prime}$ end of transcripts, estimation of the concentrations of the correct ending 3' CCA species in each batch of transcripts was performed according to (11).

For the tRNA ${ }^{\text {His }}$ transcripts, double stranded plasmid encoding the tRNA sequence was linearised by EcoT22I and transcribed in vitro as described in (26). After phenol extraction, transcripts were ethanol precipitated and purified by $12 \%$ PAGE followed by electroelution. This allowed to separate transcripts ending with the correct $3^{\prime}$ sequence from those presenting one or two additional nucleotides.

\section{Aminoacylation assays}

Aminoacylation assays were performed at $30^{\circ} \mathrm{C}$ in either $55 \mathrm{mM}$ Tris- $\mathrm{HCl} \mathrm{pH} 7.5,15 \mathrm{mM} \mathrm{MgCl} 2,10 \mathrm{mM}$ ATP, $2.5 \mathrm{mM}$ glutathione, $30 \mathrm{mM} \mathrm{KCl}, 50 \mu \mathrm{M}$ labelled amino acid (condition 1) or $25 \mathrm{mM}$ Tris- $\mathrm{HCl} \mathrm{pH} 8.5,7.5 \mathrm{mM} \mathrm{MgCl} 2,0.5 \mathrm{mM} \mathrm{ATP}$, $50 \mu \mathrm{M}$ labelled amino acid (condition 2), and the required concentrations of transcript and aminoacyl-tRNA synthetase. Aliquots were spotted on $3 \mathrm{MM}$ Whatman paper at different times and trichloroacetic acid precipitated. Kinetic parameters $\left(\mathrm{K}_{\mathrm{M}}\right.$ and $V_{\max }$ ) were determined from Lineweaver-Burk plots.

\section{Periodate oxidation}

Oxidation of the $3^{\prime}$ terminal adenosine of the TYSma transcript was performed on $40 \mu \mathrm{M}$ RNA by $1 \mathrm{mM}$ sodium periodate in darkness during 45 min. Reaction was stopped by glycerol (10 $\mathrm{mM}$ final concentration). After $5 \mathrm{~min}$ incubation, the transcript was ethanol precipitated and dried. 


\section{RESULTS AND DISCUSSION}

Search of aminoacyl-tRNA synthetases that catalyse the mischarging of TYMV RNA

In previous work we have shown that an in vitro transcript corresponding to the 258 nucleotides from the $3^{\prime}$ end of TYMV (plus 6 extra non-viral nucleotides at the $5^{\prime}$ end) (Fig. 1A) is a very efficient substrate for ValRS (11). The ability of this transcript (TYSma) to be charged by four aminoacyl-tRNA synthetases other than ValRS has now been tested. Of the four aminoacyl-tRNA synthetases tested, those specific for arginine, aspartic acid, histidine and phenylalanine, only HisRS gave charging levels above background (Table 1). The maximal histidinylation plateaus reached were $0.25 \mathrm{~mol} / \mathrm{mol}$ of input valylatable transcripts ; the plateaus were sensitive to the enzyme concentration (not shown) as well as to solvent conditions. While histidine charging reached about $0.13 \mathrm{~mol} / \mathrm{mol}$ at a $\mathrm{Mg}^{2+} / \mathrm{ATP}$ ratio of 1.5 , it is increased to $0.25 \mathrm{~mol} / \mathrm{mol}$ at a $\mathrm{Mg}^{2+} / \mathrm{ATP}$ ratio of 15 (Table 1 ). This behaviour is reminiscent of that observed in many mischarging reactions of canonical tRNAs (e.g.(35)). The inability of periodate-oxidized transcript to accept histidine (not shown) demonstrates that the histidinylation of TYSma is not artefactual. No mischarging by ArgRS, AspRS, or PheRS were observed in a variety of experimental conditions, including in the presence of dimethylsulfoxide, an additive known to stimulate incorrect aminoacylations $(35,36)$.

These results indicate that identity elements recognized by yeast HisRS are present in the TYMV tRNA-like structure (discussed below). Interestingly, Van Belkum et al. (28) also observed histidine charging with RNAs extracted from TYMV virions $(0.08 \mathrm{~mol} / \mathrm{mol})$. On the basis of the results in Table 1 , we suggest that the data of the dutch group were not due to contaminating
tRNA $^{\text {His }}$ but rather reflect histidinylation of the viral RNA by $E$. coli HisRS. The absence of charging by PheRS, AspRS and ArgRS presumably reflects either the absence within the TYMV transcript of sufficient identity elements specific for these synthetases, or the presence of conformational features (e.g. the pseudoknot) that prevent a productive interaction between the viral RNA and these synthetases, or both. It seems likely that conformational incompatibility is the major reason for the lack of phenylalanylation: the TYMV tRNA-like structure possesses two identity nucleotides of yeast $\mathrm{tRNA} \mathrm{A}^{\text {Phe }}$ (in the anticodon, and at the discriminator base adjacent to the $\left.3^{\prime} \mathrm{CCA}\right)(37)$, as does E. coli tRNA $^{\mathrm{Val}}$ (38) which is mischarged by yeast PheRS.

It is interesting that the newly discovered histidinylation of TYMV RNA involves an aminoacyl-tRNA synthetase that is already known to charge viral RNAs, those of the tobamoviruses, including tobacco mosaic virus (39). ValRS and HisRS belong to aminoacyl-tRNA synthetase class I and II, respectively (40), suggesting that the recognition and charging of extra-large noncanonical substrates is not a characteristic of a single class, and is thus not related to the structural motifs or reaction mechanisms of a specific class. Additional mischargings of viral tRNA-like structures, including TYMV RNA, cannot thus be excluded, but await further studies. ThrRS could be a potential candidate catalyzing such mischarging since it was already shown that it can accomodate an extra-large RNA substrate $(41,42)$. This holds true for ArgRS (43) and AspRS (43) which could possibly charge tRNA-like structures other than TYMV.

Comparison between the histidinylation of TYSma RNA $(n=264 n t)$ and a yeast tRNA ${ }^{\text {Hs }}$ transcript

A Lineweaver-Burk analysis of the histidinylation of TYSma RNA and a yeast tRNA ${ }^{\text {His }}$ transcript (Fig. 1B) by yeast HisRS

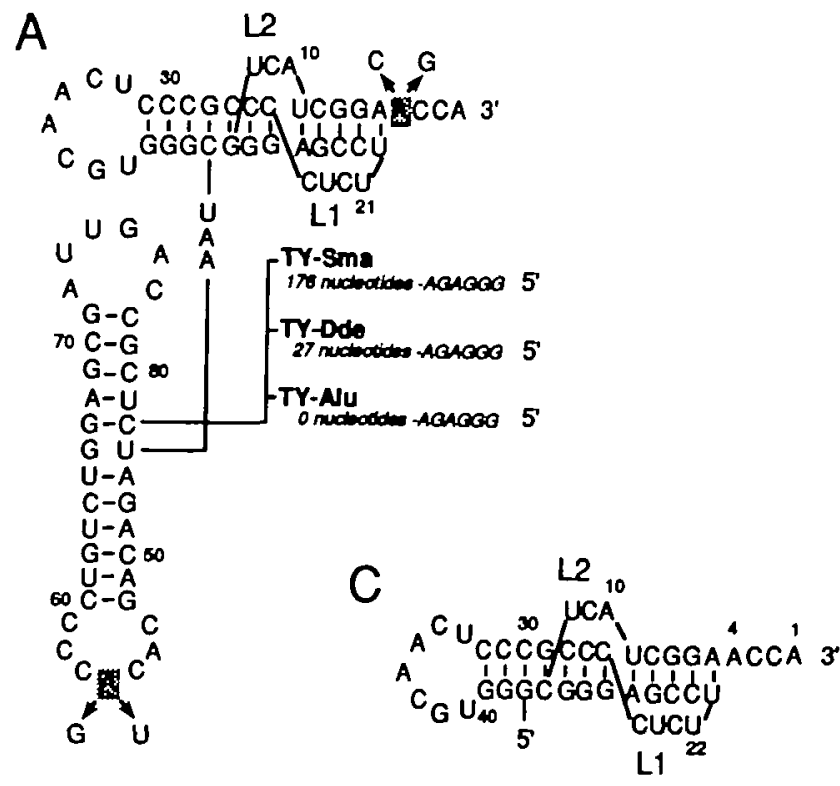

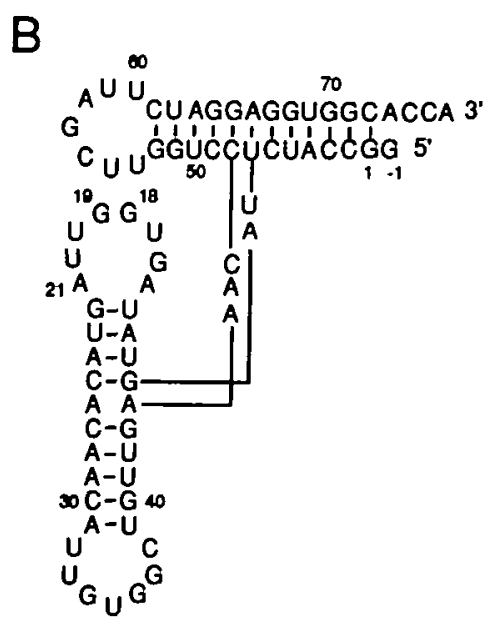

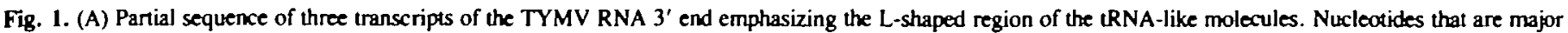

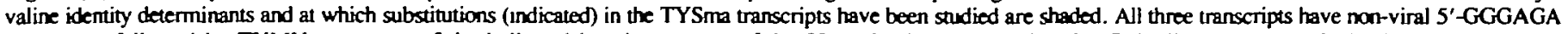

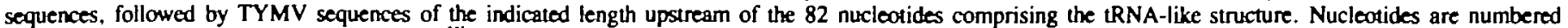

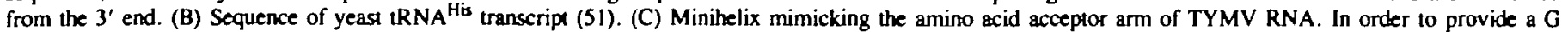

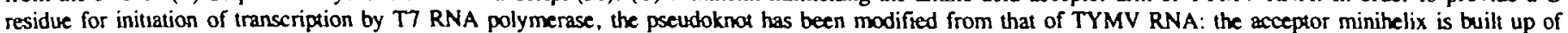

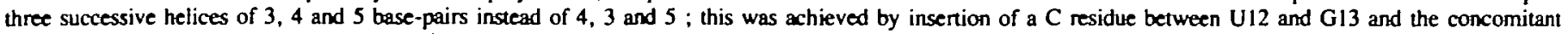
deletion of C42. As a consequence, loop L2 crosses 4 base-pairs instead of 3. 
was made, using experimental conditions favouring the mischarging of the viral RNA (i.e. $\mathrm{Mg}^{2+} / A T P$ ratio of 15). The tRNA $^{\text {His }}$ transcript was clearly a better substrate than the TYSma transcript (Table 2). The suboptimal nature of TYSma RNA as a HisRS substrate appears not to be due to poor recognition, since $K_{M}$ was even reduced by a factor of about 3 relative to the tRNA ${ }^{H r s}$ transcript. There is significant kinetic discrimination, however, evidenced by a $\mathrm{V}_{\max }$ that is reduced by a factor of 275 as compared to the tRNA ${ }^{\text {His }}$ transcript. The loss of specificity as a substrate for yeast HisRS, expressed as the relative $\mathrm{V}_{\max } / \mathrm{K}_{\mathrm{M}}$, was thus 100 -fold. This loss in specificity is relatively moderate when compared to values determined for the mischarging of canonical tRNAs: for instance, a 12000-fold loss for yeast tRNA ${ }^{\text {Met }}$ mischarging by yeast ValRS (relative to yeast tRNA ${ }^{\mathrm{V}}$ ) $(5)$ and a 13000 -fold loss for yeast tRNA ${ }^{\text {Asp }}$ mischarging by yeast ArgRS (relative to yeast tRNA ${ }^{A r g}$ ) (27).

\section{Histidinylation of TYMV fragments of various lengths}

Because fragments considerably shorter than the 264 nucleotidelong TYSma RNA are capable of mimicking the L-shaped fold of a tRNA (82 nt; Fig. 1A) $(44,45)$ and of supporting valylation $(82-84 \mathrm{nt})(11,46)$, we tested the histidinylation properties of two shorter RNAs containing the tRNA-like structure, TYDde (109 viral $\mathrm{nt}$ ) and TYAlu (82 viral nt). Both RNAs were more efficiently histidinylated than TYSma (Table 2). Transcript TYAlu, which is the shortest RNA capable of forming a complete tRNA-like structure, appears to be a very good substrate for yeast HisRS, with only a 5 -fold loss of specificity $\left(\mathrm{V}_{\max } / \mathrm{K}_{\mathrm{M}}\right.$ relative

Table 1. Level of charging ( $\%$ of aminoacylation) of TYSma transcript by various yeast aminoacyl-tRNA synthetases.

\begin{tabular}{lll}
\hline $\begin{array}{l}\text { yeast aminoacyl-tRNA synthetase } \\
\text { (specificity) }\end{array}$ & condition $1 *$ & condition $2 *$ \\
\hline Valine & $100 \%$ & $100 \%$ \\
Arginine & $<1 \%$ & $<1 \%$ \\
Aspartic acid & $<1 \%$ & $<1 \%$ \\
Histidine & $13 \%$ & $25 \%$ \\
Phenylalanine & $<1 \%$ & $<1 \%$ \\
\hline
\end{tabular}

* See section Materials and Methods for details. Aminoacylation extents were calculated taking into account a percentage of $50 \%$ of the transcripts terminating with the CCA sequence. to that of the $\mathrm{RRNA}^{\mathrm{His}}$ transcript). Thus, it appears that the minimal sequence involved in folding the tRNA-like structure contains all the important features to make TYMV RNA a good substrate for yeast HisRS, and that the 5 ' flanking region has a negative influence on the histidinylation reaction, perhaps by acting as a structural antideterminant (27) that hinders recognition by the HisRS.

\section{Histidinylation of a minihelix containing a pseudoknot}

While aminoacyl-tRNA synthetases in some cases accept extralarge non-canonical substrates such as the viral tRNA-like structures, certain synthetases are able to aminoacylate minisubstrates. This was first demonstrated for $E$. coli AlaRS, which can efficiently charge alanine onto a minihelix that mimics the amino acid acceptor arm of tRNA ${ }^{A a}$ (47), and has subsequently been observed in the histidine system from $E$. coli (48). Accordingly, we cloned and transcribed in vitro an RNA fragment that mimics the amino acid acceptor arm of the TYMV tRNA-like structure and tested its histidinylation properties. This transcript, TYAA (Fig. 1C), was designed to contain a pseudoknot slightly different from that of TYMV RNA (see Fig. 1A, 1C) in order to accommodate 5' sequences necessary for efficient transcription by T7 RNA polymerase. TYAA RNA is indeed a substrate for yeast HisRS (Table 2). This noncanonical minihelix is well recognized by the synthetase as deduced from the $K_{M}$ which is approximately the same as that of the tRNA ${ }^{\mathrm{His}}$ transcript, and, although the $\mathrm{V}_{\max }$ is decreased by a factor of 68 relative to that of the tRNA ${ }^{\text {His }}$ transcript, the histidinylation specificity (relative $V_{\max } / K_{M}$ ) is decreased by only a factor of 55 .

The aminoacylation of a short pseudoknotted fragment of viral RNA suggests that as yet undetected truncated tRNA-like structures with tRNA mimicry may be present in RNA viral genomes. Interestingly, the $3^{\prime}$ end of tobacco rattle viral RNA can be folded into a pseudoknotted structure like an amino acid acceptor arm, although no anticodon-like region or entire Lshaped tRNA-like structure exists (49). This holds true for phage MS2 RNA with the difference that there is no pseudoknonted structure in the acceptor arm (50). Although no aminoacylation of these viral RNAs has been detected, it is possible that they evolved from progenitors with entire tRNA-like structures capable of aminoacylation or alternatively, they may represent a step in evolution towards molecules more closely mimicking tRNA.

Table 2. Kinetic parameters of histidinylation of various TYMV RNA transcripts, of natural tRNA ${ }^{\text {Val }}$, and of yeast tRNA ${ }^{\text {His }}$ transcript.

\begin{tabular}{|c|c|c|c|c|c|}
\hline RNA & $\begin{array}{l}\text { Level of } \\
\text { histidinylation }\end{array}$ & $\begin{array}{l}\mathrm{K}_{\mathrm{M}} \\
(\mathrm{nM})\end{array}$ & $\begin{array}{l}V_{\max } \\
\text { (arbitrary units) }\end{array}$ & $\begin{array}{l}\mathrm{V}_{\max } / \mathrm{K}_{\mathrm{M}} \\
\text { (arbitrary units) }\end{array}$ & $\begin{array}{l}\text { Loss of } \\
\text { specificity }\end{array}$ \\
\hline tRNA $^{\text {Hs }}$ transcripk & $100 \%$ & 415 & 8500 & 20 & 1 \\
\hline TYSma $(n=264 *)$ & $25 \%$ & 155 & 31 & 0.20 & 100 \\
\hline TYDde $\left(n=115^{*}\right)$ & $60 \%$ & 725 & 280 & 0.38 & 53 \\
\hline TYAlu $\left(\mathrm{n}=88^{*}\right)$ & $85 \%$ & 290 & 1240 & 4.27 & 4.7 \\
\hline TYAA $(n=42)$ & $35 \%$ & 345 & 125 & 0.36 & 55 \\
\hline TYSma-G56* & $85 \%$ & 50 & 45 & 0.9 & 22 \\
\hline TYSmea-US6* & $95 \%$ & 45 & 45 & 1.0 & 20 \\
\hline TYSma-C4* & $45 \%$ & 240 & 110 & 0.45 & 44 \\
\hline TYSma-G4* & $60 \%$ & 200 & 40 & 0.20 & 100 \\
\hline yeast tRNA ${ }^{\mathrm{Val}}$ & $30 \%$ & 320 & 25 & 0.08 & 250 \\
\hline
\end{tabular}

* These transcripts of 258, 109 and 82 genomic nucleotides, respectively, contain a 5 ' extension of 6 nucleotides originating from the cloning process. 


\section{Relationship between histidine and valine identities}

These studies report the first direct evidence for an efficient mischarging of a tRNA-like molecule, and demonstrates that the 3' end of TYMV RNA (at least for short fragments) has a dual specificity for both ValRS and HisRS. Since the major identity elements for specific valylation of TYMV RNA by yeast ValRS have been found (34), it was possible to verify whether these are also involved in histidine charging. To determine whether the identity elements for valylation and histidinylation are overlapping or independent, we tested the histidine charging of variants of the TYSma transcript mutated in the nucleotides with major valine identity, namely the middle position of the anticodon and the residue adjacent to the $3^{\prime}$ CCA end. All mutants (TYSmaG56, TYSma-U56, TYSma-C4 and TYSma-G4) were efficiently recognized and charged by HisRS, as seen by comparison of the kinetic parameters of histidinylation summarized in Table 2. By contrast, these mutants had lost significant valylation specificity, with $V_{\max } / K_{M}$ values decreased by 29 to 28000 -fold relative to TYSma (34). Thus, it is clear that the set of identity nucleotides recognized by ValRS and HisRS are different and independent.

The identity determinants for yeast HisRS have not previously been described. Our results clearly show that major histidine determinants are located within the amino acid acceptor stem of TYMV RNA. Comparison of the sequences of all eucaryotic IRNA ${ }^{\text {His }}$ species $(51)$ reveals as an unique feature the presence of a $\mathrm{G}$ residue at position -1 at the $5^{\prime}$ end of these tRNAs. The analogous nucleotide in TYAA RNA is U22 within loop L1 of the pseudoknot (note that numbering of the viral tRNA-like structure begins at the $3^{\prime}$ adenosine). On the basis of experimental and theoretical studies $(45,52)$, this uracil 22 was proposed to be stacked on top of the major helix of the acceptor arm, in a position to base-pair with nucleotide A4. Since the mutants TYSma-C4 and TYSma-G4 have kinetic parameters similar to that of TYSma (Table 2), it is clear that the presence of a basepair involving A4 at the end of the amino acid acceptor arm is not important for histidinylation. Indeed, yeast tRNA ${ }^{\text {His }}$ does not have a $-1 / 73$ base-pair (51), and presumably G-1 is able to stack on top of $\mathrm{Gl}$ in the acceptor helix, as is proposed for the $\mathrm{U}$ residue of pseudoknot loop L1 of TYMV RNA. We suggest that the phosphate backbone of this stacked extension of the amino acid acceptor stem is a critical feature recognized by HisRS, since little or no sequence specificity has been observed (Table 2). This feature seems to be retained in evolution since nucleotide G-1 is the major identity element in $E$. coli $\operatorname{tRNA}^{\mathrm{His}}$ (53) and may explain the weak histidinylation of yeast tRNA ${ }^{\text {val }}$ (Table 2). Possibly, the sequence or topology of the acceptor arm (compare in Fig. 1 the pseudoknot design in the minihelix and the wildtype TYMV RNA sequence) may also play a role in the histidine identity of TYMV RNA, but alternatively the more efficient histidinylation of TYAlu relative to TYAA could also suggests the presence of additional histidine identity elements within the tRNA-like structure outside the amino acid acceptor arm.

\section{Perspectives and virological implications}

A comparison of the valylation and histidinylation efficiencies of TYMV RNA indicates that the viral RNA should be considered an RNA specific for valine charging, but which can be significantly mischarged with histidine. The valylation of TYMV RNA is about 20 times less efficient than that of yeast tRNA ${ }^{\text {val }}$ (5) while we have shown here that the histidinylation of TYSma RNA is about 100 times less efficient than that of the yeast tRNA $^{\text {His }}$ transcript. Nevertheless, it will be of great interest to determine whether TYMV RNA can be significantly histidinylated by a more homologous HisRS of higher plant origin in vitro and in vivo during infection. If in vivo histidinylation of TYMV RNA is in fact significant, then TYMV RNAs with anticodon mutations that destroy valylation should similarly be histidinylated (see TYSma-G56 or TYSma-U56, Table 2). Since such mutants replicated at only very low rates in chinese cabbage protoplasts (17), the observed correlation between valylation and replication (17) could be considered to refer specifically to valylation rather than to aminoacylation in general. Alternatively, if higher plant HisRS is unable to charge TYMV RNA as well as the yeast enzyme, then the results reported here provide encouragement that a TYMV RNA with improved histidine identity can be constructed by mutagenesis to test the effect of histidinylation during infection.

Our findings on the dual charging of TYMV RNA fragments are relevant to the cowpea strain of tobacco mosaic virus (CcTMV), which in contrast to other tobamoviruses binds valine rather than histidine (54) and has a tRNA-like structure similar to that of TYMV. Using a mixture of yeast aminoacyl-tRNA synthetases, a very low but significant histidine charging $(0.01$ $\mathrm{mol} / \mathrm{mol}$ ) of CcTMV RNA was found (54). Our findings on the histidinylation of TYMV RNA open the possibility that CcTMV RNA likewise possesses significant histidine identity, perhaps more so as a substrate for higher plant than for yeast HisRS (histidinylation by yeast HisRS seems to be minimal (54)), and that such histidinylation may be relevant to the replication of this tobamoviral RNA.

\section{ACKNOWLEDGEMENTS}

We thank Dr. F.W.Studier (Brookhaven) for T7 RNA polymerase clone. This work was supported by grants from the Centre National de la Recherche Scientifique (CNRS), Ministère de la Recherche et de la Technologie (MRT), Université Louis Pasteur (Strasbourg), National Science Foundation (to TWD), and by an award from the Human Frontier Science Program.

\section{REFERENCES}

I. Mans, R.M.W., Pieij, C.W.A. and Bosch, L. (1991) Eur. J. Biochem. 201, 303-324.

2. Pínck, M., Yot, P., Chapeville, F. and Duranton, H. (1970) Nature 226, 954-956.

3. Hall, T.C., Shih, D.S. and Kaesberg, P. (1972) Biachem. J. 129, 969-976.

4. Kohl, R.J. and Hall, T.C. (1974) J. Gen. Viral. 25, 257-261.

5. Giege, R., Briand, J.P., Mengual, R., Ebel, J.P. and Hirth, L. (1978) Eur. J. Biachem. 84, 251-256.

6. Joshi, S., Hacenni, A.L., Hubert, E., Huez, G. and Marbaix, G. (1978) Nature 275, 339-341.

7. Loesch-Fries, L.S. and Hall, T.C. (1982) Narure 298, 771-773.

8. Joshi, S., Chapeville, F. and Haenni, A.L. (1982) EMBO J. 1, 935-938.

9. Dreher, T.W., Bujarski, J.J. and Hall, T.C. (1984) Narure 311, 171-175.

10. Miller, W.A., Bujarski, J.J., Dreher, T.W. and Hall, T.C. (1986) J. Mol. Biol. 187, 537-546.

11. Drether, T.W., Florentz, C. and Giegt, R. (1988) Biochimie 70, 1719-1727.

12. Dreher, T.W., Rao, A.L.N. and Hall, T.C. (1989) J. Mol. Biol. 206, $425-438$.

13. Dreher, T.W. and Hall, T.C. (1988) In 'RNA Genetics' (Domingo, E., Holland, J.J. and Ahlquist, P. eds) vol. 1, pp. 91-113, CRC Press Inc., Boca Raton, Florida.

14. Florentz, C., Briand, J.P. and Giege, R. (1984) FEBS Lett. 176, 295-300.

15. Haenni, A.L., Joshi, S. and Chapeville, F. (1982) Prog. Nucl. Acid Res. Mol. Biol. 27, 85-104.

16. Quıvy, J.P. and Chroboczek, J. (1991) Biachimie 73, $1269-1273$.

17. Tsai, C.H. and Dreher, T.W. (1991) J. Virol. 65, 3060-3067.

18. Dreher, T.W. and Hall, T.C. (1988) J. Mol. Biol. 201, 4l-55. 
19. Weiner, A.M. and Maizels, N. (1987) Proc. Natl. Acad. Sci. U.S.A. 84, $7383-7387$.

20. Gallie, D.R., Feder, J.N., Schimke, R.T. and Walbot, V. (1991) Nucleic Acids Res. 19, $5031-5036$.

21. Rao, A.L.N., Dreher, T.W., Marsh, L.E. and Hall, T.C. (1989) Proc. Nall. Acad. Sci. U.S.A. 86, 5335-5339.

22. Mertes, M., Peters, M.A., Mahoney, W. and Yarus, M. (1972) J. Mol. Biol. 71, 671-685.

23. Ebel, J.P., Giege, R., Bonnet, J., Kern, D., Befort, N., Bollack, C., Fasiolo, F., Gangloff, J. and Dirheimer, G. (1973) Biochimie 55, 547-557.

24. Giege, R., Kern, D., Ebel, J.P., Grosjean, H., De Henrau, S. and Chantrenne, H. (1974) Eur. J. Biochem. 45, 351-362.

25. Grosjean, H., Charlier, J., Darte, C., Ditheimer, G., Gegé, R., De Henau, S., Keith, G., Parfait, R. and Takada, C. (1976) Experientia 347-362.

26. Perret, V., Garcia, A., Puglisi, J., Grosjean, H., Ebel, J.P., Florentz, C. and Giegé, R. (1990) Biochimie 72, 735-744.

27. Perret, V., Garcia, A., Grosjean, H., Ebel, J.P., Florentz, C. and Giege, R. (1990) Nature 344, 787-789.

28. Van Belkum, A., Bingkun, J., Rietveld, K., Pleij, C.W.A. and Bosch, L. (1987) Biochemistry 26, 1144-1151.

29. Kem, D., Giege, R., Robbe-Saul, S., Boulanger, Y. and Ebel, J.P. (1975) Biochimie 57, 1167-1176.

30. Lorber, B., Kern, D., Dietrich, A., Gangloff, J., Ebel, J.P. and Gege, R. (1983) Biochem. Biophys. Res. Commun. 117, 259-267.

31. Gangloff, J., Schutz, A. and Dirheimer, G. (1976) Eur. J. Biochem. 65, $177-182$.

32. Mengual, R. (1977) These de l'Universite Louis Pasteur, Strasbourg, France.

33. Wyatt, J.R., Chastain, M. and Puglisi, J.D. (1991) BioTechniques 11, $764-769$.

34. Florentz, C., Dreher, T.W., Rudinger, J. and Giegt, R. (1991) Eur, J. Biochem. 195, 229-234.

35. Giegé, R., Kern, D. and Ebel, J.P. (1972) Biochimue 54, 1245-1255.

36. Yarus, M. and Mertes, M. (1973) J. Biol. Chem. 248, 6744-6749.

37. Sampson, J.R., DiRenzo, A.B., Behlen, L.S. and Uhlenbeck, O.C. (1989) Science 243, 1363-1366.

38. Kem, D., Giegé, R. and Ebel, J.P. (1972) Eur. J. Biochem. 31, 148-155.

39. Oberg, B. and Philipson, L. (1972) Biochem. Biophys. Res. Commun. 48, 927-932.

40. Eriani, G., Delarue, M., Poch, O., Gangloff, J. and Moras, D. (1990) Nature 347, 203-206.

41. Moine, H., Romby, P., Springer, M., Grunberg-Manago, M., Ebel, J.P., Ehresmann, C. and Ehresmann, B. (1988) Proc. Natl. Acad. Sci. U.S.A. $85,7892-7896$.

42. Graffe, M., Dondon, J., Caillet, J., Romby, P., Ehresmann, C., Ehresmann, B. and Springer, M. (1992) Science in press.

43. Perret, V., Florentz, C. and Giege, R. (1990) FEBS Letr. 270, 4-8.

44. Rietreld, K., Van Polgeest, R., Pleij, C.W.A., Van Boom, J.H. and Bosch, L. (1982) Nucleic Acids Res. 10, 1929- 1946.

45. Dumas, P., Moras, D., Florentz, C., Giegé, R., Verlaan, P., Van Belkum, A. and Pleij, C.W.A. (1987) J. Biomol. Siruc. Dym. 4, 707-728.

46. Joshi, S., Chapeville, F. and Haenni, A.L. (1982) Nucleic Acids Res. 10 , $1947-1962$.

47. Francklyn, C. and Schimmel, P. (1989) Nature 337, 478-481.

48. Francklyn, C. and Schimmel, P. (1990) Proc. Natl. Acad. Sci. U.S.A. 87. $8655-8659$.

49. Van Belkum, A., Comelissen, B., Linthors, H., Bol, J., Pieij, C. and Bosch, L. (1987) Nucleic Acids Res. 15, 2837-2850.

50. Adhin, M.R., Alblas, J. and Van Duin, J. (1990) Biochim. Biophys. Acta 654, $249-255$.

51. Sprinzl, M., Dank, N., Nock, S. and Schrōn, A. (1991) Nucleic Acids Res. 19, Supplement, $2127-2171$.

52. Puglisi, J.D., Wyatt, J.R. and Tinoco, I. (1991) Acc. Chem. Res. 24, $152-158$.

53. Himeno, H., Hasegawa, T., Ueda, T., Watanabe, K., Miura, K. and Shimizu, M. (1989) Nucleic Acids Res. 17. 7855-7863.

54. Beachy, R.N., Zaitlin, M., Bruening, G. and Israel, H.W. (1976) Virology 73, 498-507. 